\title{
Anthropogenic impact on the presence of $L$. monocytogenes in soil, fruits, and vegetables
}

\author{
Barbara Szymczak • Mariusz Szymczak • \\ Wojciech Sawicki • Waldemar Dąbrowski
}

Received: 2 July 2012 / Accepted: 22 May 2013 / Published online: 18 June 2013

(C) The Author(s) 2013. This article is published with open access at Springerlink.com

\begin{abstract}
The aim of this study was to determine the prevalence of Listeria sp. and Listeria monocytogenes in soil samples with reference to type of fertilizers (natural and artificial) and distance from places intensively exploited by men, as well as to determine the relationship between the presence of L. monocytogenes in the soil and in fruits and vegetables. The examined 1,000 soil samples originated from 15 different areas, whilst 140 samples of fruits and 210 samples of vegetables were collected from those areas. L. monocytogenes was isolated only from $5.5 \%$ of all soil samples coming exclusively from meadows intensively grazed by cattle $(27.8 \%)$ and areas near food processing plants $(25 \%)$ and wild animal forests $(24 \%)$. Listeria sp. and L. monocytogenes were not present on artificially fertilized areas and wastelands. L. monocytogenes was detected in $10 \%$ of samples of strawberry, $15 \%$ of potato samples, and $5 \%$ of parsley samples. Our data indicate that Listeria spp. and particularly L. monocytogenes were found in the soil from (1) arable lands fertilized with manure, (2) pasture (the land fertilized with feces of domestic animals), and (3) forests (again, the land fertilized with feces of animals, not domestic but wild). The bacteria were not detected in the soil samples collected at (1) artificially fertilized arable lands and (2) wastelands (the lands that were not fertilized with manure or animal feces). Moreover, a correlation was determined in the presence of L. monocytogenes between soil samples and samples of the examined fruits and vegetables.
\end{abstract}

B. Szymczak $(\triangle) \cdot$ W. Sawicki $\cdot$ W. Dąbrowski

Department of Microbiology and Applied Biotechnology, West

Pomeranian University of Technology, Papieża Pawła VI 3,

71-459 Szczecin, Poland

e-mail: barbara.szymczak@zut.edu.p1

M. Szymczak

Department of Food Science and Technology, West Pomeranian University of Technology, Papieża Pawła VI 3,

71-459 Szczecin, Poland

\section{Introduction}

The genus Listeria comprises nine species: Listeria monocytogenes, Listeria ivanovii, Listeria innocua, Listeria welshimeri, Listeria seeligeri, Listeria grayi, Listeria marthii (Graves et al. 2010), Listeria rocourtiae (Leclercq et al. 2010) and Listeria weihenstephanensis (Halter et al. 2012), among which only L. monocytogenes is pathogenic to humans and $L$. ivanovii to animals causing listeriosis. $L$. monocytogenes is especially dangerous to humans from the group of young, old, pregnant, and immunocompromised patients. About $17 \%$ of listeriosis cases occur during pregnancy (www.fda.gov/downloads/Food/FoodborneIllness Contaminants/UCM312787.pdf). L. monocytogenes causes encephalitis and aseptic meningitis. In the USA, an estimated number of 1,600 persons become seriously ill with listeriosis each year. Although L. monocytogenes is not the most numerous bacteria found in food, it is considered to be much more dangerous in comparison with other pathogens, since 20 $30 \%$ of all listeriosis cases are fatal (Reissbrodt 2004).

The first information on the presence of $L$. monocytogenes in soil was published in 1960 by Welshimer. The object of Weis and Seeliger (1975) research were plants (corn, wheat, and oat) as well as soil from the area of their tillage. Almost $10 \%$ of corn and $13 \%$ of other plants were contaminated by L. monocytogenes. Strains of these bacteria were isolated three times more often from nonarable fields (44\%) than from the ones of intensive cultivation (12.5\%). L. monocytogenes was suggested to occur in the relation soilplants-animals-food. Since then, it is generally believed that L. monocytogenes is permanently present in soil (Weis and Seeliger 1975). Some scientists claim that L. monocytogenes is as common in nature as lactic fermentation bacteria. Listeria strains have been isolated from more than 50 hematocryal and homeothermic species including arthropods, fish, and birds (Hird and Genigeorgis 1990; Hellstrom et al. 2007; Szymczak et al. 2013; Zaremba and 
Borowski 2001). The presence of L. monocytogenes in wandering rodent populations is of great epidemiological importance because of its contact with breeding animals, humans, and consumed food. This bacterium was isolated from dairy products, meat, fruits, and vegetables (Hayes et al. 1986; Donelly 1990; Wang and Slavik 2005). Recent works by Nightingale et al. (2004) indicate that L. monocytogenes was most often isolated from farms of intensive cattle graze. In addition, a research by Sauders et al. (2012) shows that Listeria sp. and L. monocytogenes bacteria were occurring only in samples originating from urban areas.

There are literature reports on several cases of listeriosis after eating raw vegetables. The most famous is the case of listeriosis, whose source of infection was cabbage fertilized with manure from sheep suffering from listeriosis - 34 cases of perinatal listeriosis and 7 cases in adults (Schlech et al. 1983). There have also been cases of listeriosis in the USA after eating salads prepared of raw vegetables (Ho 1986) and in Sweden after eating mushrooms (Nguyen-the and Karlin 1994). Recent outbreaks of listeriosis were reported in the USA after consumption of melons, which resulted in 30 fatal cases (MMWR 2011). The source of L. monocytogenes contamination of fruits and vegetables is the soil. The main reasons of contamination include the use of contaminated manure to fertilize the soil and the purity of water used for washing vegetables and fruits. The quality of these raw materials is evaluated by the consumer based on the appearance and freshness. Despite reports about L. monocytogenes occurrence in food, there is little information about its presence in soil and about characteristics of the sampling sites. Therefore, the aim of this study was to determine the prevalence of Listeria sp. and L. monocytogenes in soil samples with reference to:

- Land management,

- Type of fertilizers: natural (manure produced from domestic animals and wildlife) and artificial (minerals produced in chemical processes),

- Distance from places intensively exploited by men, and

- Determine a relationship between the presence of $L$. monocytogenes in the soil and in fruits and vegetables. Achieving this aim will allow to determine a correlation in the presence of L. monocytogenes between soil and fruit/vegetable samples.

\section{Materials and methods}

\section{Soil}

In the years 2008-2011, 1,000 soil samples were examined, all collected in Poland (Table 1). The samples were collected in the same climate, the same latitude, and time of year, with an area of about $250 \mathrm{~km}^{2}$. That particular territory covers small areas with intensive cattle pasture, but mostly includes artificially fertilized agricultural areas and waste grounds. That information was gathered through a survey carried out with farmers. The samples were taken from areas intensively exploited by men (arable lands, areas near food processing plants, meadows intensively grazed by cattle), forests, confined wild animal breeding (boars, roes, deer, and fallow deer), as well as from wastelands. In the case of the area near food processing plants, samples were collected at a distance of $150 \mathrm{~m}$ from the plant, whereas in the case of meadows $\mathrm{A}$ and $\mathrm{B}$ - at a distance of $500 \mathrm{~m}$. The distance between meadows A and B was $80 \mathrm{~km}$. They differed in the species of cattle that was grazing on (A-dairy cattle, $\mathrm{B}$ - meat cattle). The samples were collected from the surface with a sterile spatula into sterile plastic bags, delivered to a laboratory within $1-2 \mathrm{~h}$ and analyzed.

Fruits and vegetables

We studied 140 samples of fruits, including: blueberries (20 samples), blackberries (20), raspberries (40), and strawberries (60), and 210 samples of vegetables, including: beetroot, cabbage, carrot, parsley, tomato, lettuce, and potato (30 samples of each). Samples of fruits and vegetables were collected from the same areas the soil samples were collected from naturally and artificially fertilized garden plots and orchards. Before the analysis, the fruits were thoroughly washed under running water, then stalked (for strawberries), while the vegetables were peeled with a sterile knife for vegetables (beetroot, carrot, parsley, and potato) and then washed under running water.

\section{Reference strains of L. monocytogenes}

The control samples were 10 reference strains of $L$. monocytogenes constituting a positive control for multiplex PCR. The reference strains of $L$. monocytogenes $(1 / 2 \mathrm{~A}, 1 / 2$ C, $125 \mathrm{w}, 150 \mathrm{w}$, and OSP 3) came from the collection of the Dipartimento di Scienze degli Alimenti in Italy. The strains CEB 3176, CEB 3609, and CEB 3628 were from the Institut Pasteur in France and BB 45262, BB 4581 from Lund University in Sweden.

Listeria isolation from soil samples

Each 25-g weighed portion of soil sample was transferred to a flask with $225 \mathrm{~mL}$ Half Fraser without selective agent (Fraser Broth 835, Oxford, England). The flask was shaken with arid glass pearls in an orbital shaker for $10 \mathrm{~min}$. The samples were incubated for $24 \mathrm{~h}$ at $30^{\circ} \mathrm{C}$. Then $1 \mathrm{~mL}$ of the culture was transferred to $10 \mathrm{~mL}$ Fraser with Fraser Selective Supplement (SR 156, Oxoid). Simultaneously, a culture into 
Table 1 Incidence of $L$. monocytogenes in soil, fruit and vegetables
${ }^{a}$ Number of analyzed samples/ percent of positive test is given as the proportion of PCR method

\begin{tabular}{|c|c|c|c|c|c|}
\hline Type of soil & No. $(\%)^{\mathrm{a}}$ & Fruit & No. $(\%)^{\mathrm{a}}$ & Vegetables & No. $(\%)^{\mathrm{a}}$ \\
\hline \multicolumn{6}{|l|}{ Arable lands: } \\
\hline \multirow[t]{7}{*}{ Natural fertilizing } & $173(1.2)$ & strawberry & $20(10.0)$ & beetroot & $10(0)$ \\
\hline & & & & cabbage & $10(0)$ \\
\hline & & & & carrot & $10(0)$ \\
\hline & & & & lettuce & $10(0)$ \\
\hline & & & & parsley & $10(5.0)$ \\
\hline & & & & potato & $10(15.0)$ \\
\hline & & & & tomato & $10(0)$ \\
\hline \multirow[t]{7}{*}{ Artificially fertilized } & $173(0)$ & strawberry & $20(0)$ & beetroot & $10(0)$ \\
\hline & & raspberry & $20(0)$ & cabbage & $10(0)$ \\
\hline & & & & carrot & $10(0)$ \\
\hline & & & & lettuce & $10(0)$ \\
\hline & & & & parsley & $10(0)$ \\
\hline & & & & potato & $10(0)$ \\
\hline & & & & tomato & $10(0)$ \\
\hline Wastelands & $120(0)$ & & & & \\
\hline \multirow[t]{7}{*}{ Garden plots } & $47(10.6)$ & strawberry & $20(10.0)$ & beetroot & $10(0)$ \\
\hline & & raspberry & $20(0)$ & cabbage & $10(0)$ \\
\hline & & & & carrot & $10(0)$ \\
\hline & & & & lettuce & $10(0)$ \\
\hline & & & & parsley & $10(5.0)$ \\
\hline & & & & potato & $10(15.0)$ \\
\hline & & & & tomato & $10(0)$ \\
\hline Orchards & $18(0)$ & & & & \\
\hline \multicolumn{6}{|l|}{ Meadows } \\
\hline Intensive dairy cattle graze (A) & $36(27.8)$ & & & & \\
\hline Intensive meat cattle graze (B) & $44(13.6)$ & & & & \\
\hline Small grazing cattle (some units) & $20(0)$ & & & & \\
\hline Wastelands & $78(0)$ & & & & \\
\hline $\begin{array}{l}\text { Confined wild animal breeding } \\
\text { (boards, deer and fallow deer) }\end{array}$ & $32(15.6)$ & & & & \\
\hline Areas near food processing plants & $36(25.0)$ & & & & \\
\hline \multicolumn{6}{|l|}{ Forests } \\
\hline Deciduous & $72(12.5)$ & blackberry & $20(0)$ & & \\
\hline Coniferous & $72(2.8)$ & blueberry & $20(0)$ & & \\
\hline Around the lake & $50(0)$ & & & & \\
\hline Area hunting districts & $29(24.0)$ & & & & \\
\hline
\end{tabular}

single colonies was performed on the Listeria Selective Agar (LSA) medium (CM 856, Oxoid, England) with Listeria Selective Supplement (SR 140, Oxoid). First, the samples were incubated on the Fraser medium and then on the LSA medium for another $48 \mathrm{~h}$ at $37{ }^{\circ} \mathrm{C}$ (Scotter et al. 2001).

\section{Listeria sp. and L. monocytogenes strains identification}

Five colonies typical of Listeria on the LSA medium were randomly chosen from each sample for further identification. The sample where at least one colony was identified with biochemical tests as Listeria sp. and as L. monocytogenes in the PCR reaction was acknowledges as positive. Strains were identified to the Listeria genus (stained preparation with Gram method, catalase, oxidase, motility at $20^{\circ} \mathrm{C}$ and $37^{\circ} \mathrm{C}$ ) and to L. monocytogenes species by API tests (BioMerièux, France).

\section{Microbial DNA isolation}

DNA isolation was performed from a 24-h microbial culture in BHI broth using Genomic Mini AX Bacteria kits (A\&A Biotechnology, Poland). The concentration and purity of 
DNA were checked spectroscopically (NanoDrop DN-1000, Biotech, USA).

\section{Multiplex PCR}

Identification to the genus Listeria was performed using primers specific for the $16 \mathrm{~S}$ rDNA sequence fragment: U1 and LI1 (Border et al. 1990). The primers iap1 (5' -CgA ATC TAA Cgg Ctg gCA CA- $\left.3^{\prime}\right)$ and iap2 (5' -gCC CAA ATA gTg TCA CCg CT- 3') specific for the iap gene fragment (Jaton et al. 1992) were used for species identification to $L$. monocytogenes. The sizes of amplified DNA sequences were $938 \mathrm{bp}$ for $16 \mathrm{~S}$ rDNA fragment and $287 \mathrm{bp}$ for iap fragment. Due to a high number of strains being identified, a multiplex PCR was performed. Multiplex PCR reaction was carried out in a volume of $50 \mu \mathrm{L}$ using Mastercycler Gradient (Eppendorf). Each reaction mixture contained $500 \mathrm{mmol} / \mathrm{L}$ $\mathrm{KCl}, 100 \mathrm{mmol} / \mathrm{L}$ Tris $-\mathrm{HCl}\left(\mathrm{pH} 8.3\right.$ at $\left.25^{\circ} \mathrm{C}\right), 2.5 \mathrm{mmol} / \mathrm{L}$ $\mathrm{MgCl}_{2}, 0.3 \mathrm{mmol} / \mathrm{L}$ of each nucleoid, $30 \mathrm{pmol} / \mathrm{L}$ of each primer, $2.5 \mathrm{U}$ Taq DNA polymerase (Eppendorf), and $5 \mu \mathrm{L}$ DNA template. The thermal profile consisted of the following stages: preliminary denaturation $-60 \mathrm{~s}$ at $95^{\circ} \mathrm{C}$ and 35 cycles including: denaturation $-30 \mathrm{~s}$ at $94^{\circ} \mathrm{C}$, primers annealing - 20s at $51^{\circ} \mathrm{C}$ and extension $30 \mathrm{~s}$ at $72^{\circ} \mathrm{C}$. The amplification ended with extension $8 \mathrm{~min}$ at $72{ }^{\circ} \mathrm{C}$.

\section{Agarose gel electrophoresis}

Eight microliters of each reaction product with $0.037 \mathrm{~g}$ of Bromophenol Blue (ICN Biomedicals INC, USA) in a $1.5 \%$ sucrose solution were separated electrophoretically under standard conditions $(5 \mathrm{~V} / \mathrm{cm})$ in a $2 \%$ agarose gel (Prona Agarose Plus). The gel was stained with ethidium bromide $(0.5 \mu \mathrm{g} / \mathrm{mL})$ in TBE buffer, observed in UV light and archived (GelDoc, BioRad). The size of the product was compared with the mass marker XVI (Roche, Germany).

\section{Statistical analysis}

The results obtained from soil, fruits, and vegetables were analyzed statistically using Spearman's correlation with a 0.05 significance level in StatSoft Statistica v 9.0 (Statsoft, Tulsa, OK, USA).

\section{Results}

\section{L. monocytogenes in soil}

The presence of $L$. monocytogenes was determined in $5.5 \%$ of 1,000 examined soil samples acknowledged by PCR multiplex reaction, as shown in Table 1. L. monocytogenes was isolated only from the areas intensively exploited by men including areas near food processing plants $(25 \%)$, meadows intensively grazed by cattle $(13.6-27.8 \%)$, and garden plots intensively fertilized with manure $(10.6 \%)$.

One hundred seventy-three organically fertilized soil samples, 173 artificially fertilized soil samples, and 120 wasteland samples were examined. L. monocytogenes was isolated only from the areas fertilized organically $(1 \%)$, whereas both Listeria sp. and L. monocytogenes did not occur in artificially fertilized areas and wastelands (Table 1).

Studies have shown that out of the 36 soil samples collected in the immediate vicinity of a meat factory, $L$. monocytogenes was isolated in $25 \%$ of the samples that originated exclusively from direct proximity to the main entrance of the plant. Listeria sp., and L. monocytogenes were not isolated from the samples located more than $50 \mathrm{~m}$ away from the food processing plant (data not shown). Out of the 36 samples collected on the meadow land A and B, the presence of L. monocytogenes was detected in 28 and $14 \%$ of the samples, respectively. The presence of Listeria species and $L$. monocytogenes was confirmed on the areas most frequently used by the livestock (near water holes and feeders). Listeria sp. and L. monocytogenes were only isolated from the areas where cattle was grazing intensively, whereas Listeria was not isolated in the distance of $150 \mathrm{~m}$ from the grazing land. Similarly as in the case of meadow A, L. monocytogenes was only isolated from the area where the cattle was grazing on (about 200 heads of cattle). In the proximity, there were meadow wastelands and forests, where not even a single Listeria colony growing characteristically on LSA was isolated. The type of cattle had no influence on the presence of these bacteria.

\section{L. monocytogenes in fruit and vegetables}

Of the 140 tested samples of fruits, L. monocytogenes was confirmed only in strawberries (10\%) from naturally fertilized land and allotments (Table 1). Using the multiplex PCR technique, L. monocytogenes was confirmed in the samples of parsley and potatoes coming from allotments and agricultural land fertilized naturally, i.e., 5 and $15 \%$, respectively (Table 1). In other samples, Listeria sp. and $L$. monocytogenes were not detected. Correlation analysis showed a significant $(P<0.05)$ relationship between the presence of $L$. monocytogenes in garden plots and strawberry $($ Rho $=0.271)$. The correlation between the fertilized land and parsley, potato, and strawberry was weak, respectively $0.086,0.042$, and 0.009 . In other cases, no correlation occurred, because all data in the variable had a zero value. The high rho value indicates a high risk of contamination of fruits and vegetables grown in the soil with L. monocytogenes bacterium. 


\section{Discussion}

"Listeria is present in the environment worldwide". This statement is often used by researchers dealing with Listeria. Publications from the 1970s are in fact the only works describing Listeria presence in soil (Weis and Seeliger 1975; Welshimer 1968; Welshimer and Donker-Voet 1971). In contrast, in recent years, L. monocytogenes has been demonstrated to occur only in strictly specified types of soil and its presence to be linked with the use of manure as an ecological crop or has been isolated from areas of farms with intensive cattle graze (Nightingale et al. 2004). Alike results were achieved in the present study, where Listeria sp. and $L$. monocytogenes were isolated from soil intensively fertilized with manure.

Soils samples were collected from areas differing in the type and class of soil; however, previous investigations did not demonstrate those factors to affect the occurrence of $L$. monocytogenes (Kwiatkowska 2008). In addition, the study demonstrated that Listeria sp. and L. monocytogenes did not occur on uncultivated agricultural and remote areas of larger agglomerations of people. On the contrary, studies by Sauders et al. (2012) showed that members of the genus Listeria were not only common in urban and natural environments but also showed species- and subtype-specific associations with different environments and areas. Similar findings were obtained in a research by Zaytseva et al. (2007) that was performed on 76 soil samples from territories of east Russia. Listeria sp. and L. monocytogenes were not isolated. The author emphasizes that those areas are distant from large urban agglomerations, food processing plants, or animal breeding farms.

The presence of $L$. monocytogenes near food processing plants is not surprising since other authors had earlier reported on a serious problem with Listeria on areas of meat plants and others plants connected with food processing. In Tompkin's research (Tompkin 2002), L. monocytogenes was isolated from food processing plant's floor. On that account, one can assume that Listeria was "carried on shoes" of workers. Earlier, L. monocytogenes was isolated from smears from floors, walls and work surfaces of a production hall. Our study confirmed the presence of L. monocytogenes in $25 \%$ of soil samples collected from the area near the food processing plant. Our study demonstrated that $L$. monocytogenes was isolated from soil at the distance of $50 \mathrm{~m}$ away from the meat processing plant (data not shown). The sources of contamination with L. monocytogenes are animal feces left with meat as a result of improperly conducted preliminary treatment. Further on, the bacteria permeate into production halls and transferred onto shoes, etc. On the other hand, the occurrence of L. monocytogenes in such a close proximity to the main entrance to the production hall is due to the washing of vehicles transporting carcasses of slaughter animals after unloading Kwiatkowska (2008).

In this work, we examined a specific territory of enclosed wild animal breeding (boars, deer, fallow deer). This was a 20-ha area, and population density was about 100 animals per ha. The presence of L. monocytogenes was determined in $15.6 \%$ of the examined samples. Similar findings were obtained by Kalorey et al. (2006), who isolated $L$. monocytogenes from $16 \%$ of feces samples from animals living in a zoo in India. Bauwens et al. (2003) demonstrated L. monocytogenes presence in 14 (7\%) feces samples of different wild animals (including $6.7 \%$ mammals and $8.6 \%$ birds) living in a zoo in Antwerp. Research on reindeer feces samples show that wild animals living in low-populated areas, e.g., northern Norway are Listeria-free (Aschfalk et al. 2003). The author emphasizes that those territories are very extensive and reindeers are wandering animals, therefore the possibility of infection of one animal from another is quite low. A potential source of L. monocytogenes strains is silage, which is often used to feed animals. Fenlon (1996) and Roberts and Wiedmann (2003) showed a lack of L. monocytogenes in feces of animals fed with green fodder, in contrast to animals fed with silage. In turn, Nightingale et al. (2004) examined 504 soil samples from 24 farms of intensive cattle graze and the presence of $L$. monocytogenes was proved in 120 of them ( $24 \%$ ). Their data suggest that (1) the epidemiology and transmission characteristics of $L$. monocytogenes differ between small ruminant and cattle farms; (2) cattle contributed to amplification and dispersal of L. monocytogenes into the farm environment; (3) the ruminant, and particularly the bovine, farm ecosystem maintains a high prevalence of $L$. monocytogenes, including subtypes linked to human listeriosis cases and outbreaks, and may thus constitute a significant natural reservoir for $L$. monocytogenes; and (4) L. monocytogenes subtypes may differ in their abilities to infect animals and to survive in farm environments.

Similar findings were obtained in our research in the case of samples collected from meadows A and B, 27.8 and $13.6 \%$, respectively. Wesley et al. (2002) showed that $L$. monocytogenes was more often isolated from cattle feces (33\%) than from sheep feces $(8 \%)$. The species of cattle had no effect on the occurrence of L. monocytogenes. In our study, 218 soil samples tested originated from forests and the presence of L. monocytogenes was detected in $8.3 \%$ of these samples. Polish forests are unique in terms of the high number of visitors (people walking, gathering fruits and mushrooms). In addition, wild animals living in forests often go to ploughland in search for food. The sources of soil contamination with L. monocytogenes in Polish forests are feces of wild boars and deers. A research by Koronkiewicz (2006) demonstrated that L. monocytogenes was confirmed in $60 \%$ samples of wild boar feces and in $43 \%$ samples of 
deer feces. In turn, in the soil samples collected from areas of hunting grounds, L. monocytogenes was isolated only from the samples originating from areas, where these bacteria were detected in feces of the game.

L. monocytogenes is a microorganism isolated from different foods, including fruits and vegetables, whether fresh, frozen, or otherwise processed. A study by Beuchat (1996) demonstrated the relationship between the use of natural organic fertilizers and the occurrence of L. monocytogenes bacteria in raw vegetables. Our study confirmed that the contamination of fruits and vegetables was related to anthropogenic factors (fertilization, irrigation, storage, transport, etc.). It showed that the fruits and vegetables contaminated with $L$. monocytogenes originated from soils fertilized with manure. Worthy of notice is also that these bacteria were isolated only from those raw materials that had contact with the soil, e.g., strawberries, root vegetables, etc. Furthermore, it was found that the occurrence of pathogenic bacteria, including Listeria sp. bacilli, was significantly affected by the method of soil fertilization, because the main source of contamination was manure. Also Heisick et al. (1989) showed that $25.8 \%$ of potato samples and $30.3 \%$ of radish samples were contaminated with L. monocytogenes. In contrast, Wong et al. (1990) showed that out of 49 tested samples of vegetables, $12.2 \%$ were contaminated with $L$. monocytogenes bacilli. In turn, in our study, the presence of L. monocytogenes in strawberries (10\%), parsley (5\%), and potatoes $(15 \%)$ may be an indicator of contamination with these bacteria. Due to the increased intake of fresh fruits and vegetables, the promotion of food from the so-called organic farming in Europe, where manure is the basic acceptable applied fertilizer that can be a source of contamination with L. monocytogenes and to the increasing number of listeriosis cases, a need emerges for greater control of food products in terms of $L$. monocytogenes presence.

In this study, correlation analyses were performed to assess the relationship between the occurrence of $L$. monocytogenes in soil and in fruits/vegetables. Soil samples were classified according to the two groups on the basis of proportional occurrence of bacteria (Table 1). Vegetables and fruits collected from the examined soils were classified into one of the two groups, depending on the degree of soil contamination. They were also classified based on the proportional occurrence of L. monocytogenes. The first group includes soils not cultivated by man or soils fertilized artificially. These soils do not pose a health threat of Listeria food poisoning, since these bacteria were not present on fruits and vegetables. The second group includes soils exploited by man for grazing cattle and those fertilized naturally. $L$. monocytogenes was present in $1.2-27.8 \%$ of the samples. Moreover, depending on the type of vegetables and fruits collected from these soils, L. monocytogenes was present in $0-15 \%$ of the samples of fruits and vegetables. The statistical analysis show only one significant correlation between the occurrence of L. monocytogenes in fruits, vegetables, and soil.

The consumption of fruits and vegetables from soils from the second group poses the high risk of infection with $L$. monocytogenes. Our study indicates that the most frequent cause of soil contamination with L. monocytogenes bacteria is manure, which is linked with the transmission of those bacteria to crops. In most cases, it refers to fruits and vegetables having direct contact with the contaminated soil (strawberries, root vegetables, etc.).

A thesis in which authors claim that soil is a natural environment for L. monocytogenes, according to present study, appears to be wrong. A total number of 1,000 soil samples and 140 fruit and 210 vegetable samples were examined, which proves reliability of the research made. Listeria spp. and particularly L. monocytogenes were found in the soil from (1) arable lands fertilized with manure; (2) pasture (the land fertilized with feces of domestic animals); and (3) forests (again, the land fertilized with feces of animals, not domestic but wild). The bacteria were not found in the soil samples collected at (1) artificially fertilized arable lands and (2) wastelands (the lands that were not fertilized with manure or animal feces). There was a correlation between the presence of bacteria in soil and in fruits/vegetables.

Acknowledgments The research was supported by the Ministry of Science and Higher Education, grant no N N312 234438.

Open Access This article is distributed under the terms of the Creative Commons Attribution License which permits any use, distribution, and reproduction in any medium, provided the original author(s) and the source are credited.

\section{References}

Aschfalk A, Kemper N, Holler C (2003) Bacteria of pathogenic importance in faeces from cadavers of free-ranging or corralled semi-domesticated reineer in northern Norway. Vet Res Commun 27:93-100

Bauwens L, Vercammen F, Hertsens A (2003) A detection of pathogenic Listeria spp. in zoo animal faeces: use of immunomagnetic separation and a chromogenic isolation medium. Vet Microbiol 91:115-123

Beuchat LR (1996) Listeria monocytogenes: incidence on vegetables. Food Control 7:223-228

Border PM, Howard JJ, Plastow GS, Siggens KW (1990) Detection of Listeria species and Listeria monocytogenes using polimerase chain reaction. Lett Appl Microbiol 11:158-162

Donelly CW (1990) Resistance of Listeria monocytogenes to heat. In: Miller AJ (ed) Smith JL. Somkuti GA, Foodborne Listeriosis, Elsevier, Amsterdam, pp 189-193

Fenlon DR (1996) The incidence and level of Listeria monocytogenes contamination of food sources at primary production and initial processing. J Appl Bacteriol 81:641-650

Graves LM, Helsel LO, Steigerwalt AG, Morey RE, Daneshvar MI, Roof SE, Orsi RH, Fortes ED, Milillo SR, Bakker HC, Wiedmann M, Swaminathan B, Sauders BD (2010) Listeria marthii sp. nov., 
isolated from the natural environment, Finger Lakes National Forest. Inter J Syst Evol Microbiol 60:1280-1288

Halter EL, Neuhaus K, Scherer S (2012) Listeria weihenstephanensis $s p$. nov., isolated from water plant Lemna trisulca of a German fresh water pond. Int $J$ Syst Evol Microbiol 63:641-647. doi:10.1099/ijs.0.036830-0

Hayes PS, Feeley JC, Graves LM, Ajello GW, Fleming DW (1986) Isolation of Listeria monocytogenes from raw milk. Appl Environ Microbiol 51:438-440

Heisick JE, Wagner DE, Nierman ML, Peeler JT (1989) Listeria spp. found on fresh market product. Appl Environ Microbiol 55:1925-1927

Hellstrom S, Kiviniemi K, Autio T, Korkeala H (2007) Listeria monocytogenes in common in wild birds in Helsinki region and genotypes are frequently similar with those found along the food chain. J Appl Microbiol 1-6

Hird DW, Genigeorgis C (1990) Listeriosis in food animals; clinical signs and livestock as a potential source of direct (nonfoodborne) infection for humans. In: Miller AJ, Smith JL, Somkuti GA (eds) Foodborne Listeriosis, red. Elsevier Science Publishers B.V, Amsterdam, pp 31-39

Ho JL, Shands KN, Freidland G, Eckind P, Fraser DW (1986) An outbreak of type $4 \mathrm{~b}$ Listeria monocytogenes infection involving patients from eight Boston hospitals. Arch Intern Med 146:520-524

Jaton K, Sahli R, Bille I (1992) Development of polymerase chain reaction assays for detection of Listeria monocytogenes in clinical cerebrospinal fluid samples. J Clin Microbiol 30:1931-1936

Kalorey DR, Kurkure NV, Warke SR, Rawool DB, Malik SVS, Barbuddhe SB (2006) Isolation of pathogenic Listeria monocytogenes in faeces of wild animals in cativity. Commpar Immunol Microbiol Infect Dis 29:295-300

Koronkiewicz A (2006) Pathogenic microorganisms in carcasses of wild game PhD Thesies. Akademia Rolnicza, Szczecin (in Polish)

Kwiatkowska B (2008) Occurence of L. monocytogenes in soil and plants. PhD Thesies, Akademia Rolnicza, Szczecin (in Polish)

Leclercq A, Clermont D, Bizet C, Grimont PAD, Fleche-Mateos AL, Roche SM, Buchrieser C, Cadet-Daniel V, Monnier A, Lecuit M, Allerberger F (2010) Listeria rocourtiae sp. nov. Inter J Syst Evol Microbiol 60:2210-2214

Morbidity and Mortality Weekly Report - MMWR (2011) Multistate outbreak of listeriosis associated with Jensen farms cantaloupe-United States, August-September 2011 60:1357-1358

Nguyen-the, Karlin F (1994) The microbiology of minimally processed fresh fruits and vegetables. Crit Rev Food Sci Nutr 34:371-401

Nightingale KK, Schukken YH, Nightingale CR, Fortes ED, Ho AJ, Her Z, Grohn YT, McDonough PL, Wiedmann M (2004) Ecology of transmission of Listeria monocytogenes infecting ruminants and in the farm environment. Appl Environ Microbiol 70:4458-4467

Reissbrodt R (2004) New chromogenic plating media for detection of pathogenic Listeria spp.—an overview. Int J Food Microbiol 95:1-9

Roberts AJ, Wiedmann M (2003) Pathogen, host and environmental factors contributing to the pathogenesis of listeriosis. Cell Mol Life Sci 60:904-918

Sauders BD, Overdevest J, Fortes E, Windham K, Schukken Y, Lembo A, Wiedmann M (2012) Diversity of listeria species in urban and natural environments. Appl Environ Microbiol 78:4420-33

Schlech WF, Lavigne PM, Bortolussi RA, Alleri AC, Haldane EV, Wort AJ, Hightower AW, Johnson SE (1983) Epidemic listeriosis - evidence for transmission by food. New Eng J Medic 308:203-206

Scotter SL, Langton S, Lombard B, Schulten S, Nagelkerke N, In't Veld PH, Rollier P, Lahellec C (2001) Validation of ISO method 11290 Part 1 - Detection of Listeria monocytogenes in foods. Inter J Food Microbiol 64:295-306

Szymczak M, Szymczak B, Koronkiewicz A, Felisiak K, Bednarek M (2013) Effect of cover brine type of the quality of meat from herring marinades. J Food Sci 78:619-625

Tompkin RB (2002) Control of Listeria monocytogenes in the foodprocessing environment. J Food Protect 65:709-725

Wang H, Slavik MF (2005) A multiplex polymerase chain reaction assay for rapid detection of Escherichia coli 0157:H7, Listeria monocytogenes, Salmonella typhimurium and Campylobacter jejuni in artificially contaminated food samples. J Rapid Methodol Automat Microbiol 13:213-223

Weis J, Seeliger HPR (1975) Incidence of Listeria monocytogenes in Nature. Appl Microbiol 30:29-32

Welshimer HJ (1968) Isolation of Listeria monocytogenes from vegetation. J Bacteriol 95:300-303

Welshimer HJ, Donker-Voet J (1971) Listeria monocytogenes in nature. Appl Microbiol 21:516-519

Wesley IV, Hormon KM, Dicson JS, Schwartz AR (2002) Application of multiplex polymerase chain reaction assay for the simultaneous confirmation of Listeria monocytogenes and other Listeria species in turkey sample surveillance. J Food Protect 65:780-785

Wong HCH, Chao W, Lee S (1990) Incidence and characterization of Listeria monocytogenes in foods available in Taiwan. App Environ Microbiol 56:3101-3104

Zaremba ML, Borowski J (2001) Mikrobiologia lekarska. PZWL, Warszawa, pp 186-210

Zaytseva E, Ermolaeva S, Somov GP (2007) Low genetic diversity and epidemiological significance of Listeria monocytogenes isolated from wild animals in the far east of Russia. Infect Genet Evol 7:736-742 